\title{
Editorial
}

\section{Asking Questions that Matter}

"For librarians, the idea of 'asking the right question' is nothing new." ${ }^{1}$ Lorie Kloda, "Asking the Right Question" (2008)

As part of its $75^{\text {th }}$ anniversary celebration, the Association of College \& Research Libraries hosted a panel on the future of research in academic

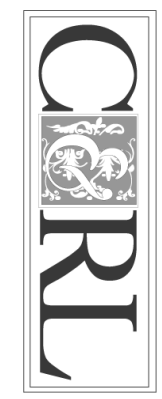
librarianship at the ACRL National Conference in Portland, Oregon.

Moderated by one of the authors, this panel was composed of prominent voices in LIS research, teaching, and practice, including James Neal, Megan Oakleaf, Denise Koufogiannakis, and CERL editorial board member John Budd. Inspired, in part, by discussions found in this journal regarding what has "counted" as legitimate research in our field over the past 75 years, as well as the direction such research might take in the future, the questions raised in Portland centered on methodology and support for LIS scholars (and scholarly practitioners) wishing to adopt new methodologies in their work. ${ }^{2}$ Which is better, quantitative or qualitative? What counts as "evidence" in evidence-based research? With so much focus on method, one might be forgiven for wondering what drives research in our field in the first place. Why conduct research in academic librarianship? Why is it valuable for practitioners to conduct research? The most recent issue of this journal presented one answer to these questions through its review of research conducted as part of the Assessment in Action program, but here, too, there was a strong focus on method. ${ }^{3}$ We work every day with students to help them to formulate their theses and arguments and to think critically about the questions they want to ask, but, in any discussion of our own research, we often jump immediately to the specific issue of method. It is as if what we are going to do and how we are going to do it take precedence over why we should be concerned with an issue. We are quite attuned to the "why" and the "what questions need to be asked" when we work with students, but less so when it comes to discussions of our own work.

This focus on method is useful for librarians conducting research, as one of the first decisions we make when we embark on a project is which method we will employ to answer our research question(s). And when we submit our work to scholarly journals, structured abstracts often require a description of method, usually a few words that name the standard approach applied by the authors. When we review work that has been submitted to a journal for publication, feedback forms typically include an area asking us to address method, both whether the method selected was appropriate to the research question articulated and whether the method was applied soundly. This pragmatic focus on method, however, neglects the ways in which certain research methods may be deemed legitimate or illegitimate by the gate-keepers patrolling the boundaries of the discipline, as well as the fact that the question comes first. So, before we consider "how did you answer the question," we should attend to "was the question worth asking" (and, keeping those gate-keepers in mind, we should also consider who might be answering that latter question in the negative).

Library and Information Science has long been pre-occupied with debates over the "best" methodology for the field. ${ }^{4}$ Heting Chu has documented the growth of methodological variety in LIS in recent decades, as the field has shifted from the dominant mode of survey research to a much broader range of approaches, including the qualitative methods advocated by Jana Bradley and others. ${ }^{5}$ By the 2000s, mixed 
methods research became more common in the field, if not always recognized by the researchers themselves. ${ }^{6}$ A number of textbooks offer a straightforward introduction to a variety of research methods currently employed in Library and Information Science, as does the American Library Association's Office for Research and Statistics. ${ }^{7}$ While this suggests that our field has embraced a broad spectrum of methods in the design of scholarly research, one of the authors recalls a number of questions regarding his decision to employ a qualitative research design in a study published in this journal as recently as 2008, and representation of a variety of perspectives on "what counts as research" continues to present a challenge in the composition of editorial boards and peer reviewer pools in leading journals in our field. ${ }^{8}$

Concerns about methodology, thus, are complementary to epistemological debates about what counts as knowledge in our field. These epistemological debates, like many in librarianship, have been conceptualized along a binary with a dominant positivism contested by the challenge of relativism. Can phenomena be apprehended once and for all by the deployment of scientific research methods, or is empirical reality "complex, intertwined, understood most fully as a contextual whole, and ultimately inseparable from the individuals 'knowing' that reality?"' 9 These two epistemological standpoints parallel the methodological approaches pitted against each other in disciplinary debates. Positivist researchers align themselves with the experiment and the survey, while phenomenologists, social constructionists, and postmodernists conduct discourse analysis and ethnography.

Michael H. Harris locates the dominance of quantitative, positivist research in our field in its origins in the profession. ${ }^{10} \mathrm{He}$ argues that librarianship was initially understood as "a mechanical art best assimilated through precept and practice," and thus its epistemological concerns were confined to questions about how we do our work, not what that work is or how it connects to larger political and economic structures. ${ }^{11}$ In the 1920 s, the field embraced the flourishing "new science" of management, placing a primacy on empirical research and the scientific method that dominates LIS research to this day. By the time Harris was writing in the 1980s, even theoretical concerns in the field had become primarily instrumental: meant to "explain, predict, and control-i.e., produce a desired state of affairs by simply applying theoretical knowledge." ${ }^{12}$ We can hear echoes of this concern in David James Hudson's recent keynote address at the Critical Librarianship and Pedagogy Symposium at the University of Arizona. In a talk that contested the relentlessly practical nature of contemporary LIS research, Hudson suggested that praxis, embraced by anti-positivists in the field as a way of returning theoretical concerns to research, tends, "at a fundamental level, to treat theory and practice as discrete phenomena, as if there are actually concrete phenomena called theory and practice that are fundamentally separate in their existence." ${ }^{13}$ In separating the two, the practical is imagined as wholly separate from the theories - or ideologies - that construct it.

These debates - quantitative vs. qualitative, positivist vs. antipositivist - are common ones in our field. Less common are conversations that explicitly address the kinds of questions to which these methodologies ought to be applied. Textbooks such as Connoway and Powell's Basic Research Methods for Librarians (2010) include a consideration of the "domain" of LIS research, and Denise Koufogiannakis and Ellen Crumley have attempted to develop a typology of research areas relevant to LIS. ${ }^{14}$ ACRL, too, has identified "research agendas" in areas such as information literacy, scholarly communications, and the value of academic libraries, and other professional associations have endorsed similar projects. ${ }^{15}$ That said, our field often stops at the articulation of general topic areas for potential research rather than doing the hard work of identifying critical questions that matter for the future of our work and its contributions to the campus, higher education, or society, more broadly. 
This is not to say that we do not, as a field, study things that matter. We ask hard questions about roles and responsibilities, teaching and learning, diversity and inclusion, scholarly communications and open access, etc., and our efforts in these areas have transformed our profession, our practice, and the institutional contexts within which we work. But, to the degree that we begin our conversations about the future of LIS research with a focus on method, we foreclose our potential to ensure that our questions have warrant and our potential to make an impact with our research that will make long hours of literature review, data gathering, and close reading of text worth the effort. Methodology, after all, is methodical. It is inescapably instrumental. When we focus on the question of which method is "best" (in our field or for a project), we invariably privilege the steps we must take to arrive at an answer, rather than on the extent to which the question is even worth asking or the degree to which a focus in our field on a particular type of question may be limiting our vision of what our work as scholar-practitioners might mean.

Take, for example, the contemporary focus of many libraries in pursuing research on the articulation of return-on-investment, quantifiable contributions to student success, and the value of academic libraries to their parent institutions. Several excellent studies along these lines have been published in this journal, including one in this issue by John K. Stemmer and David M. Mahan on the relationship between undergraduate student use of library resources and student learning outcomes. ${ }^{16}$ We are not quite to the point that Neal was when he urged his audience at the ACRL National Conference in Philadelphia to "stop the madness" of ROI studies in academic libraries, but we do find the broader context within which "value" studies are conducted worthy of critical attention. ${ }^{17}$ In her executive summary of the Value of Academic Libraries report that launched this research agenda, Oakleaf noted that accrediting bodies, government officials, and other authorities in educational oversight now conceive of institutions of higher education as "producers of a commodity - student learning," which means, in turn, that "[academic] librarians no longer can rely on their stakeholders' belief in their importance. Rather, they must demonstrate their value." ${ }^{18}$ In the years since her report was published, the field has exploded with initiatives like Assessment in Action that funnel Association resources toward the goal of measuring the contributions libraries make to the success of their institutions according to the metric of student learning, and our literature has become filled at every stage with "value" studies. The pragmatic need for research that ensures consideration of the library in a higher education environment increasingly framed by learning analytics, performance metrics, and the corporatization of academic values leaves little room for arguments - research based or otherwise - that appeal to the prima facie value of libraries as the heart of the academic enterprise.

We are not arguing against "value" research, and we are glad to see the agenda outlined by Oakleaf coming to fruition in initiatives like Assessment in Action that provide real benefit to librarians undertaking work that has improved their practice and helped them to open the door to meaningful collaboration with campus colleagues. For those of us working in tuition-dependent institutions, every student who we fail to retain can mean the loss of operational funds that translate into reductions to the materials budget, loss of positions, and deferred opportunities to make needed upgrades to library facilities and technology. Having the tools to communicate with senior leadership on our campuses about the value of the library in the language employed in the contemporary higher education environment can make a real difference in the life of working librarians. That said, we must be mindful of the ways in which such efforts, and the research we do to support them, may serve to normalize the problem itself. Are we content to live in a world where learning is a commodity that can be administratively produced and where we measure our worth as librarians by our place on a dashboard? We recognize 
the strategic need for many libraries to operate in this environment in order to ensure that they may continue to operate at all, but we should also ask ourselves how our framing of the problem limits the questions we can ask and the solutions we can imagine to the fundamental question of the role of the library in the academic enterprise and of our roles, as librarians, in higher education. Can we imagine interventions that librarians might make that would help to undo the commodification of learning, or have we, by privileging the questions related to determining and articulating our "value," limited the scope of our vision for the future of our field?

We are very interested in the future of LIS research, and hope that the Portland panel, with its focus on methods and on models for supporting research in the workplace, was the start of an ongoing conversation. Methods give librarians the tools with which to answer research questions central both to curiosity and to daily practice, and having an ample toolbox with which to do that work is important. But it is just as important to know what we want to build and who it will benefit as it is to make sure that we have the tools to do the work. It has been just over a decade since Michael K. Buckland challenged us to pursue "grand challenges" in library research, and, while we might quibble with some of the perspectives Buckland advanced, we appreciate that his research agenda included an array of questions inclusive of the more practical and the more theoretical. Theory and practice should be mutually informative in our field, and inquiry into "values" should occupy as privileged a place as inquiry into "value." We look forward to seeing both in the future issues of this journal.

\section{Emily Drabinski \\ Long Island University}

Scott Walter

DePaul University

\section{Post-Script:}

This is my final editorial for College $\mathcal{E}$ Research Libraries, as Wendi Arant Kaspar will take my place as editor-in-chief with the July 2016 issue. I joined the editorial board of CERL in 2008, not long after my article, "Librarians as Teachers: A Qualitative Inquiry into Professional Identity," was published in the journal. Those were exciting times for the Board, as we discussed, and eventually adopted, the open-access model for publication that many of us believed was critical if we were to have a legitimate stake in the scholarly communications discussions we were promoting on our home campuses. In 2012, I was named editor-designate, but had to take on the editorial responsibility more quickly than expected following the illness and untimely death of my friend and predecessor, Joseph Branin. My four years as editor saw us embrace a digital-only publication model, launch a social media program, adopt altmetrics and other approaches to ensure a broad view of the reach and impact of the work published in the journal, and more. It has remained an exciting time to be a member of the Board, and there are still many opportunities ahead of us, so I continue to recommend it as a service opportunity for anyone wishing to influence the future of scholarly communications in our field. I would like to take this opportunity to thank all the members of the editorial board with whom I have served during the past 8 years, our colleagues who have contributed guest editorials or served as peer reviewers for incoming manuscripts, and our ACRL staff partners, David Free and Dawn Mueller. It is not uncommon for almost 150 submissions to come to CERL in a given year, and my own thinking about our field has been enriched by the opportunities I have had to read, and comment on, all of that work. 
Finally, I would be remiss if I failed to note that my fellow editorial writers and I have raised many questions in these pages and have outlined some work that we felt needed to be done. I'm looking forward to turning my attention to some of those opportunities now that Wendi is ready to take the helm at $C \mathcal{E} R L$ and I hope I'll have the chance to continue working with many of you on those issues (and others) in the coming years.

Scott Walter

DePaul University

\section{Notes}

1. Lorie Kloda, "Asking the Right Question," Evidence Based Library and Information Practice 3 (2008): 79-81, accessed April 8, 2016. https://ejournals.library.ualberta.ca/index.php/EBLIP/article/ view/4426/3725.

2. James Elmborg and Scott Walter, "Critical Thinking About 'Getting Research Published' in College \& Research Libraries," College \& Research Libraries 76, no. 1 (2015): 2-5, accessed April 8, 2016. http://crl.acrl.org/content/76/1/2.full.pdf+html.

3. Kara J. Malenfant, Lisa Janicke Hinchliffe, and Debra Gilchrist, "Assessment as Action Research: Bridging Academic Scholarship and Everyday Practice," College \& Research Libraries 77, no. 2 (2016): 140-143, accessed April 8, 2016. http://crl.acrl.org/content/77/2/140.full.pdf+html.

4. Veronica Gauchi Risso, "Research Methods Used in Library and Information Science During the 1970s-2010s," New Library World 117, no. 1/2 (2016): 74-93.

5. Heting Chu, "Research Methods in Library and Information Science: A Content Analysis," Library and Information Science Research 37, no. 1 (2015): 36-41; Jana Bradley, "Methodological Issues and Practices in Qualitative Research," Library Quarterly 63, no. 4 (1993): 431-449.

6. Raya Fidel, "Are We There Yet?: Mixed Methods Research in Library and Information Science," Library and Information Science Research 30, no. 4 (2008): 265-272.

7. Lynn S. Connoway and Ronald R. Powell, Basic Research Methods for Librarians ( $5^{\text {th }}$ ed.) (Santa Barbara, CA: Libraries Unlimited, 2010); Barbara M. Wildemuth, Applications of Social Research Methods to Questions in Information and Library Science (Westport, CT: Libraries Unlimited, 2009); American Library Association, "Research Methods," accessed April 9, 2016, http://www.ala.org/ research/larks/researchmethods.

8. Elmborg and Walter, "Critical Thinking About 'Getting Research Published' in College \& Research Libraries."

9. Bradley, "Methodological Issues and Practices in Qualitative Research": 432.

10. Michael H. Harris, "The Dialectic of Defeat: Antimonies in Research in Library and Information Science," Library Trends 34, no. 3 (1986): 515-531.

11. Ibid., 516.

12. Ibid., 518.

13. David James Hudson, "On Critical Librarianship and Pedagogies of the Practical," Keynote address delivered at the Critical Librarianship and Pedagogy Symposium, Tuscon, Arizona, February 25-26, 2016.

14. Denise Koufogiannakis and Ellen Crumley, "Research in Librarianship: Issues to Consider," Library Hi Tech 24, no. 3 (2006): 324-340.

15. See, for example: Association of College and Research Libraries, "Research Agenda for Library Instruction and Information Literacy," accessed April 17, 2016, http://www.ala.org/acrl/ aboutacrl/directoryofleadership/sections/is/iswebsite/projpubs/researchagendalibrary; Association of College and Research Libraries, "ACRL Scholarly Communications Research Agenda," accessed April 17, 2016, http://www.ala.org/acrl/issues/scholcomm/scresearch04; American Association of Law Libraries, "AALL Research Agenda, 2013-2016," accessed April 17, 2016, http:// www.aallnet.org/mm/Member-Resources/grants/research-grants/research-agenda.html.

16. John K. Stemmer and David M. Mahan, "Investigating the Relationship of Library Usage to Student Outcomes," College \& Research Libraries 77, no. 3 (2016).

17. James G. Neal, "Stop the Madness: The Insanity of ROI and the Need for New Qualitative Measures of Academic Library Success." Paper presented at the ACRL National Conference, Philadelphia, Pennsylvania, March 30-April 2, 2011, accessed April 17, 2016, http://www.ala. org/acrl/sites/ala.org.acrl/files/content/conferences/confsandpreconfs/national/2011/papers/ stop_the_madness.pdf.

18. Megan Oakleaf, The Value of Academic Libraries: A Comprehensive Research Review and Report (Chicago: Association of College \& Research Libraries, 2010), accessed April 17, 2016, http:// www. ala.org/ala/mgrps/divs/acrl/issues/value/val_report.pdf. 